\title{
Desain Desentralisasi Asimetris Dalam Sistem Ketatanegaraan Republik Indonesia
}

\author{
Gunawan A. Tauda \\ Fakultas Hukum, Universitas Khairun \\ gunawan.tauda@gmail.com
}

\begin{abstract}
This study aims to know the design of asymmetric decentralization in the state administration system of the Republic of Indonesia. The research method used in the research is legal research that uses a conceptual approac. The results show that asymmetric decentralization in Indonesia is a historical continuity that has been started from the colonial period and confirmed to date in the 1945 Constitution of the Republic of Indonesia. As a reality of the practice of regional government, the constitutional juridical legitimacy of asymmetric decentralization can be referred to in Article 18A paragraph (1), and Article 18B paragraph (1) of the Constitution of the Republic of Indonesia as the supreme law of the land. Asymmetric decentralization concerns fundamental matters related to the pattern of relations between the center and the regions regarding different authority, institutional, financial and control designs.
\end{abstract}

Keywords: Asymmetric Decentralization, State Administration System, Indonesian Government

\begin{abstract}
Abstrak
Penelitian ini bertujuan utnuk menegtahui desain Desentralisasi Asimetris Dalam Sistem Ketatanegaraan Republik Indonesia. Metode penelitian yang digunakan dalam penelitian adalah penelitian hukung yang menggunakan pendekatan kosnep (conceptual approac). Hasil penelitian menujukan bahwa Desentralisasi asimetris di Indonesia merupakan sebuah keberlanjutan sejarah yang telah dimulai dari masa kolonial dan ditegaskan hingga saat ini dalam UUD NRI Tahun 1945. Sebagai sebuah realitas praktik pemerintahan daerah, legitimasi yuridis konstitusional dari desentralisasi asimetris tersebut dapat dirujuk dalam Pasal 18A ayat (1), dan Pasal 18B ayat (1) Konstitusi Republik Indonesia sebagai hukum tertinggi negara (the supreme law of the land). Desentralisasi asimetris menyangkut urusan yang fundamental terkait pola hubungan pusat dan daerah menyangkut desain kewenangan, kelembagaan, finansial dan kontrol yang berbeda.
\end{abstract}

Kata Kunci: Desentralisasi Asimetris, Sistem Ketatanegaraan, Permerintah Indonesia 


\section{A. Pendahuluan}

Undang-Undang Dasar Negara Republik Indonesia Tahun 1945 telah mengatur secara garis besar mengenai konsep otonomi daerah di Indonesia. Dalam Pasal 18 ayat (2) dan ayat (5) UUD NRI Tahun 1945 ditentukan bahwa Pemerintahan Daerah Provinsi, Daerah Kabupaten, dan Kota mengatur dan mengurus sendiri urusan pemerintahan menurut asas otonomi dan tugas pembantuan. Pemerintahan daerah menjalankan otonomi seluas-luasnya, kecuali urusan pemerintahan yang oleh undang-undang ditentukan sebagai urusan Pemerintah Pusat. ${ }^{1}$ Secara umum, otonomi daerah sebagai perwujudan dari desentralisasi kekuasaan, dimaknai sebagai wewenang untuk mengatur dan mengurus rumah tangga daerah, yang melekat baik pada negara kesatuan maupun pada negara serikat. Di dalam negara kesatuan, otonomi daerah lebih terbatas dari otonomi daerah pada negara serikat. Kewenangan mengatur dan mengurus rumah tangga daerah di negara kesatuan meliputi segenap kewenangan pemerintahan, kecuali beberapa urusan yang dipegang oleh pemerintah pusat.

Lebih lanjut, mengenai hubungan antara Pemerintah Pusat dan Pemerintah Daerah, Pasal 18A UUD NRI Tahun 1945 menyatakan bahwa: (1) hubungan wewenang antara pemerintah pusat dan pemerintahan daerah provinsi, kabupaten dan kota, atau antara provinsi dan kabupaten dan kota, diatur dengan undangundang dengan memperhatikan kekhususan dan keragaman daerah; (2) hubungan keuangan, pelayanan umum, pemanfaatan sumber daya alam dan sumber daya lainnya antara pemerintah pusat dan pemerintah daerah diatur dan dilaksanakan secara adil dan selaras berdasarkan undang-undang.

Frasa "dengan memperhatikan kekhususan dan keragaman daerah" dalam Pasal 18A ayat (1) UUD NRI Tahun 1945 ini sebenarnya mengindikasikan bahwa konstitusi menghendaki adanya pengaturan yang berbeda bagi tiap-tiap daerah yang mempunyai corak khusus dan beragam. Hal ini semakin diperkuat dengan adanya Pasal 18B UUD NRI Tahun 1945 yang menyatakan bahwa (1) Negara

\footnotetext{
1 Pasal 10 ayat (1) Undang-Undang Nomor 23 Tahun 2014 tentang Pemerintahan Daerah menyatakan bahwa urusan pemerintahan yang menjadi "Urusan Pemerintahan Absolut" pemerintah pusat meliputi: politik luar negeri, pertahanan, keamanan, yustisi, moneter dan fiskal nasional, serta agama.
} 
mengakui dan menghormati satuan-satuan pemerintahan daerah yang bersifat khusus atau bersifat istimewa yang diatur dengan undang-undang; (2) Negara mengakui dan menghormati kesatuan-kesatuan masyarakat hukum adat beserta hak-hak tradisionalnya sepanjang masih hidup dan sesuai dengan perkembangan masyarakat dan prinsip Negara Kesatuan Republik Indonesia, yang diatur dalam undang-undang. Dengan demikian, politik hukum (legal policy) tentang desentralisasi yang digariskan UUD NRI Tahun 1945 mengisyaratkan keniscayaan penerapan "desentralisasi asimetris" yang menekankan kekhususan, keistimewaan, keberagaman daerah, serta kesatuan-kesatuan masyarakat hukum adat dan hak-hak tradisional yang diatur lebih lanjut dengan undang-undang.

Desentralisasi asimetris (asymmetrical decentralisation) adalah pemberlakuan/transfer kewenangan khusus yang hanya diberikan pada daerahdaerah tertentu dalam suatu negara, yang dianggap sebagai alternatif untuk menyelesaikan permasalahan hubungan antara pemerintah pusat dan pemerintah daerah, dalam konteks Indonesia dalam rangka menjaga eksistensi daerah dalam NKRI. ${ }^{2}$ Desentralisasi asimetris mencakup desentralisasi politik, ekonomi, fiskal, dan administrasi, namun tidak harus seragam untuk semua wilayah negara, dengan mempertimbangkan kekhususan masing-masing daerah. Penerapan kebijakan desentralisasi asimetris merupakan sebuah manifestasi dari usaha pemberlakuan keistimewaan. Konsep tersebut sebenarnya sudah dijalankan dalam praktik ketatanegaraan Republik Indonesia, yaitu dengan adanya beberapa daerah yang berstatus istimewa/berotonomi khusus seperti Provinsi Papua \& Papua Barat, Provinsi Aceh, Provinsi Daerah Khusus Ibukota Jakarta, dan Provinsi Daerah Istimewa Yogyakarta. Kelima provinsi ini secara legal formal sudah memperoleh pengakuan dari negara. Inti desentralisasi asimetris adalah terbukanya ruang gerak implementasi dan kreativitas provinsi dalam pelaksanaan pemerintahan daerah di luar ketentuan umum dan khusus yang diatur dalam

\footnotetext{
${ }^{2}$ Sebagai catatan, dalam konteks hukum pemerintahan daerah, desentralisasi asimetris merupakan kontra konsep dari desentralisasi simetris (symmetrical decentralisation) yang berlaku di 29 daerah provinsi di Indonesia. Konsep desentralisasi simetris (desentralisasi yang seragam) menekankan pada pelimpahan kewenangan yang menjadi kewenangan pemerintahan daerah kepada keseluruhan daerah-daerah dalam negara secara uniformistik. Dalam tatanan praktik ketatanegaraan, Republik Indonesia saat ini menerapkan kedua konsep ini secara bersamaan.
} 
Undang-Undang Nomor 23 Tahun 2014 tentang Pemerintahan Daerah, ataupun peraturan perundang-undangan lainnya. ${ }^{3}$

\section{B. Pembahasan}

\section{Dasar-dasar Pelaksanaan Desentralisasi Asimetris Indonesia Kontemporer}

Dalam penelitian yang dilakukan oleh Jurusan Politik dan Pemerintahan Fisipol UGM (JPP-UGM 2010) menunjukkan setidaknya terdapat lima alasan mengapa desentralisasi asimetris harus dilakukan di Indonesia. ${ }^{4}$

Pertama, alasan konflik dan tuntutan separatisme. Tidak dapat dipungkiri, dua daerah (tiga Provinsi) yaitu Provinsi Aceh, Provinsi Papua dan Provinsi Papua Barat mendapatkan perlakuan khusus dalam bentuk otonomi khusus karena konflik antara kedua daerah tersebut dengan pemerintah nasional yang antara lain karena perebutan sumber daya. Jika diringkas, otsus untuk Aceh dan Papua secara prinsipil terdiri dari: Pertama, dana Otonomi Khusus sebagai kompensasi ketiga provinsi masih dapat bergabung di Republik Indonesia. Kedua, pengakuan terhadap identitas lokal yang terwujud dalam institusi politik. Di Aceh proses ini ditandai dengan adanya lembaga baru yang merepresentasikan adat dan agama. Di Papua, wewenang diberikan kepada adat dan gereja. Ketiga, pengakuan terhadap simbol-simbol lokal seperti bendera, bahasa dan lain sebagainya. Keempat, partai politik lokal. Aceh memanfaatkan momentum partai lokal dengan tumbuhnya partai lokal dan memenangkan pemilu, sedangkan di Papua belum ada walaupun ruang untuk hal tersebut telah ada. Kelima, adanya afirmatif action untuk menjadi pemimpin lokal. Di Aceh wujudnya dengan dapat membaca Al Quran, di Papua pemimpinnya harus orang asli papua yang disyahkan oleh Majelis Rakyat Papua.

\footnotetext{
${ }^{3}$ Sebagai misal, Undang-Undang Nomor 1 Tahun 2015 tentang Pengesahan Peraturan Pemerintah Pengganti Undang-Undang Nomor 1 Tahun 2014 tentang Pemilihan Gubernur, Bupati dan Walikota menjadi Undang-Undang, sebagaimana telah diubah terakhir dengan Undang-Undang Nomor 10 Tahun 2016 tentang Perubahan Kedua Atas Undang-Undang Nomor 1 Tahun 2015 tentang Pengesahan Peraturan Pemerintah Pengganti Undang-Undang Nomor 1 Tahun 2014 Tentang Pemilihan Gubernur, Bupati dan Walikota menjadi Undang-Undang, sebagian materi muatannya tidak diterapkan sepenuhnya/dikesampingkan berdasarkan prinsip lex specialist derugat legi generalist, dalam hal pengisian jabatan Gubernur dan Wakil Gubernur di lima provinsi di atas.

4 Bayu Dardias Kurniadi, "Desentralisasi Asimetris di Indonesia”, Makalah disampaikan pada Seminar di LAN Jatinangor tanggal 26 November 2012. hlm. 8-9.
} 
Keenam dan mungkin paling penting, pengaturan terkait sumber daya. Selain dana otsus yang jumlahnya sangat besar, pengelolaah sumberdaya daerah adalah isu yang spesifik. Aceh memiliki beberapa kekhususan spesifik terkait dengan pengelolaan sumber daya, misalnya pertanahan, hutan dan eksploitasi minyak.

Kedua, alasan ibukota negara. Perlakuan khusus ini hanya diberikan untuk Provinsi DKI. Mengingat DKI yang wilayahnya terjangkau dengan infrastuktur terbaik di negeri ini, perlakuan khusus diwujudkan dalam ketiadaan pemilukada untuk Bupati/Walikota dan tidak ada DPRD Kabupaten/Kota yang ditunjuk oleh Gubernur. Konsekuensinya, pemilukada Gubernur menggunakan sistem mayoritas bersyarat dimana pemenang yang ditetapkan memperoleh suara lebih dari 50\%. Di daerah lain, kecuali Yogyakarta, cukup mendapatkan suara mayoritas sederhana.

Ketiga, alasan sejarah dan budaya. Daerah Istimewa Yogyakarta mendapatkan perlakuan istimewa mengingat sejarahnya di masa revolusi dan perebutan kemerdekaan. Perlakuan ini terlihat dari penetapan Gubernur dan Wakil Gubernur di DIY yang dilakukan oleh DPRD. Gubernur DIY adalah Sultan yang bertahta dan Wakil Gubernur DIY adalah Pakualam yang bertahta. Penentuan Sultan dan Pakualam diserahkan kepada institusi keraton/pakualam masingmasing. Kedua pemimpin ini tidak boleh bergabung dengan partai politik. Pada level kabupaten/kota tetap sama dengan daerah lainnya.

Keempat, alasan perbatasan. Perbatasan perlu mendapatkan perlakuan khusus mengingat perannya sebagai batas teritorial dengan negara tetangga. Daerah perbatasan memegang fungsi penting karena kompleksitas masalah yang dihadapi. Daerah perbatasan harus diperlakukan sebagai halaman depan dan bukan halaman belakang Republik Indonesia. Perlakukan daerah perbatasan, misalnya di Kalimatan Utara, dan Kalimantan Utara hendaknya berbeda, misalnya dengan mewajibkan gubernurnya berasal dari kalangan militer karena potensi pelintas batas yang tinggi disamping penguatan infratruktur dan pelayanan pendidikan dan kesehatan. Detail tentang asimetrisme perbatasan masih membutuhkan kajian lebih lanjut.

Kelima, pusat pengembangan ekonomi. Daerah yang secara geografis memiliki peluang untuk menjadi daerah khusus ekonomi seharusnya 
dikembangkan agar memiliki daya saing ekonomi tinggi. Daerah seperti Batam dapat dikembangkan dan dibentuk untuk menyaingi Singapura. Alokasi kekhususan misalnya menyangkut bea masuk dan pengembangan infrastruktur pengembangan ekonomi seperti pelabuhan dan tata sistem pelabuhan. Pelabuhan terbesar di Indonesia saat ini, Tanjung Priok di Jakarta lebih untuk memenuhi kebutuhan dalam negeri karena posisi geografisnya. Jika Batam dikembangkan dengan pelabuhan modern dengan sistem yang baik, tidak mustahil mampu mengambil potensi pelabuhan Singapura yang memiliki keterbatasan ruang. Detail tentang asimetrisme pengembangan ekonomi masih membutuhkan kajian lebih lanjut.

\section{Pelaksanaan Desentralisasi Asimetris dalam Praktik Ketatanegaraan Republik Indonesia}

\section{a) Provinsi Daerah Khusus Ibu Kota}

Pemberian status khusus kepada Daerah Khusus Ibukota Jakarta (DKI Jakarta) lebih ditekankan pada aspek historisnya. Keberadaan DKI Jakarta dalam sejarah perjuangan kemerdekaan bangsa Indonesia tidak bisa lepas dari dipilihnya Jakarta sebagai tempat diselenggarakan peristiwa-peristiwa besar bangsa Indonesia. Selain pernah dikenal sebagai Batavia, Jakarta juga menjadi tempat pusat pergerakan seperti lahirnya Boedi Oetomo, Sumpah Pemuda, hingga Proklamasi kemerdekaan 1945. Konsentrasi pemerintahanan kekuasaan inilah yang kemudian menjadikan Jakarta sebagai Ibukota negara. ${ }^{5}$

Dalam perkembangannya, pemberian status keistimewaan Jakarta ini telah ada melalui Penetapan Presiden Nomor 2 Tahun 1961 tentang Pemerintahan Daerah Khusus Ibukota Jakarta Raya oleh Presiden Soekarno. Lebih lanjut bahwa dasar pemberian ini adalah: ${ }^{6}$

1. Jakarta sebagai ibukota negara patut dijadikan indoktrinasi, kota teladan dan kota cita-cita bagi seluruh bangsa Indonesia;

5 Andhika Yudha Pratama, "Pelaksanaan Desentralisasi Asimetris dalam Tata Kelola Pemerintahan Daerah di Era Demokrasi”, Jurnal Pendidikan Pancasila dan Kewarganegaraan, Th. 28, Nomor 1, Februari 2015, hlm. 8.

${ }^{6}$ Ibid., hlm. 8-9. 
2. sebagai ibukota negara, daerah Jakarta Raya perlu memenuhi syarat-syarat minimun dari kota internasional dalam waktu yang sesingkat-singkatnya;

3. untuk menciptakan tujuan tersebut di atas, maka Jakarta Raya harus diberikan kedudukan yang khusus sebagai daerah yang langsung dikuasai oleh Presiden/ Pemimpin Besar Revolusi.

Aturan yang dikeluarkan ini berkonsekuensi Jakarta diberikan kewenangan khusus yang langsung berada di bawah Presiden. Memasuki pemerintahan Soeharto, keistimewaan yang diberikan pemerintah pusat kepada DKI Jakarta berupa gubernur yang didampingi oleh 5 orang wakil gubernur. ${ }^{7}$

Pasca runtuhnya pemerintahan yang sentralisitik dan kemudian berhembusnya angin bercorak desentralistik yang menghinggapi pemerintahan daerah di Indonesia, DKI Jakarta turut pula mengalami perubahan. Ada hal yang khusus didapatkan oleh DKI Jakarta, mimpi besar presiden Soekarno tentang grand design DKI Jakarta sebagai kota internaional membuat pembanguanan di Jakarta begitu intens. Di samping itu, selain Gubernur dilibatkan dalam rapat kabinet presiden yang menyangkut urusan tata kelola ruang di Ibukota, DKI Jakarta tidak perlu melakukan pemilihan kepada daerah tingkat kota. Pemilihan walikota di DKI Jakarta dipilih oleh Gubernur atas pertimbangan DPRD Provinsi dari pegawai negeri sipil yang memenuhi syarat. Dengan sistem sedemikian rupa, maka Walikota bertanggung jawab kepada Gubernur dengan olah wewenang berupa garis komando. ${ }^{8}$

Selain hal-hal tersebut di atas, Berdasarkan Undang-Undang Nomor 29 Tahun 2007 tentang Pemerintahan Provinsi Daerah Khusus Ibukota Jakarta sebagai Ibukota Negara Kesatuan Republik Indonesia, kekhususan DKI Jakarta meliputi hal-hal sebagai berikut:

1. Otonomi tunggal di tingkat provinsi. Selain di Jakarta, otonomi daerah di seluruh wilayah NKRI dilekatkan ke kota/kabupaten. Sedangkan di Jakarta, kota bukanlah daerah otonom melainkan hanya wilayah administrasi kerja. Sehingga penyebutannya pun Kota Administrasi (Pusat,

\footnotetext{
${ }^{7}$ Ibid., hlm. 9.

${ }^{8}$ Ibid.
} 
Utara, Barat, Selatan dan Timur) dan Kabupaten Administrasi Kepulauan seribu. Konsekuensinya adalah, Walikota dan Bupati di Jakarta bukanlah jabatan politis melainkan jabatan struktural birokrasi. Karaena itu tidak ada pemilihan (pilkada) walikota/bupati, karena jabatan tersebut, sebagaimana disebutkan sebelummya, diisi oleh PNS yang ditunjuk oleh gubernur. Kewenangannya tentu berbeda dengan kabupaten/kota otonom. Juga tidak ada DPRD Kabupaten/Kota di wilayah DKI Jakarta. APBD pun hanya di tingkat provinsi, yang di dalamnya mencakup alokasi untuk 6 kabupaten/kota, 44 kecamatan dan 267 kelurahan.

2. Dalah hal pemilihan calon gubernur dan wakil gubernur, pasangan calon Gubernur dan Wakil Gubernur yang memperoleh suara lebih dari 50\% (lima puluh persen) ditetapkan sebagai Gubernur dan Wakil Gubernur terpilih. Dalam hal tidak ada pasangan calon Gubernur dan Wakil Gubernur yang memperoleh suara sebagaimana dimaksud, diadakan pemilihan Gubernur dan Wakil Gubernur putaran kedua yang diikuti oleh pasangan calon yang memperoleh suara terbanyak pertama dan kedua pada putaran pertama. Ketentuan ini merupakan lex specialist dari UndangUndang Nomor 1 Tahun 2015 tentang Pengesahan Peraturan Pemerintah Pengganti Undang-Undang Nomor 1 Tahun 2014 tentang Pemilihan Gubernur, Bupati dan Walikota menjadi Undang-Undang, sebagaimana telah diubah terakhir dengan Undang-Undang Nomor 10 Tahun 2016 tentang Perubahan Kedua Atas Undang-Undang Nomor 1 Tahun 2015 tentang Pengesahan Peraturan Pemerintah Pengganti Undang-Undang Nomor 1 Tahun 2014 Tentang Pemilihan Gubernur, Bupati dan Walikota menjadi Undang-Undang. Berdasarkan Undang-Undang Pemilihan ini, tidak dikenal adanya sistem dua putaran, dan berlaku sistem mayoritas sederhana dalam kontestasi pemilihan kepala daerah.

3. Selain seorang wakil gubernur, terdapat pula empat Deputi Gubernur yang membantu Gubernur Jakarta. Berbeda dengan wakil gubernur yang dipilih sebagai pasangan calon dalam pilkada, Deputi adalah jabatan birokratis dengan eselonering yang sama dengan Sekretaris Daerah. Pembidangan 
untuk empat deputi itu adalah: Tata Ruang dan Lingkungan Hidup, Pengendalian Kependudukan dan Permukiman, Industri, Perdagangan dan Transportasi; serta Pariwisata dan Kebudayaan.

4. Gubernur dapat menghadiri sidang kabinet yang menyangkut kepentingan Ibukota Negara Kesatuan Republik Indonesia.

5. Pemerintah dapat membentuk dan/atau menetapkan kawasan khusus di wilayah Provinsi DKI Jakarta untuk menyelenggarakan fungsifungsi pemerintahan tertentu yang bersifat khusus bagi kepentingan nasional sesuai dengan ketentuan peraturan perundang-undangan.

6. Gubernur mempunyai hak protokoler, termasuk mendampingi Presiden dalam acara kenegaraan sesuai dengan ketentuan peraturan perundangundangan.

\section{b) Provinsi Daerah Istimewa Yogyakarta}

Status keistimewaan Provinsi DIY diatur dalam Undang-Undang Nomor 13 Tahun 2012 tentang Keistimewaan DIY. Dalam konsideran Undang-Undang Keistimewaan DIY tersebut, ditegaskan bahwa negara berlandaskan pada UUD NRI 1945 yang mengakui dan menghormati satuan-satuan pemerintahan daerah yang bersifat khusus atau bersifat istimewa yang diatur dengan undang-undang. Serta dinyatakan pula bahwa Kasultanan Ngayogyakarta Hadiningrat dan Kadipaten Pakualaman yang telah mempunyai wilayah, pemerintahan, dan penduduk sebelum lahirnya Negara Kesatuan Republik Indonesia pada tanggal 17 Agustus 1945, berperan dan memberikan sumbangsih yang besar dalam mempertahankan, mengisi, dan menjaga keutuhan Negara Kesatuan Republik Indonesia.

Selanjutnya dalam Pasal 1 ayat (1) : dinyatakan yang dimaksud DIY ialah daerah provinsi yang mempunyai keistimewaan dalam penyelenggaraan urusan pemerintahan dalam kerangka Negara Kesatuan Republik Indonesia. Pasal 1 ayat (1) ini menunjukkan negara menerapkan desentralisasi asimetris dimana dinyatakan dalam pasal tersebut provinsi DIY memiliki keistimewaan. Keistimewaan dalam Pasal 1 ayat (2) adalah keistimewaan kedudukan hukum 
yang dimiliki oleh DIY berdasarkan sejarah dan hak asal-usul menurut UndangUndang Dasar Negara Republik Indonesia Tahun 1945 untuk mengatur dan mengurus kewenangan istimewa.

Kemudian yang menarik selanjutnya ialah negara mengakui kerajaan yang memang sejak dulu, sebelum Indonesia merdeka sudah ada di Yogyakarta yang terdiri dari Kesultanan dan Pakualaman. Hal ini dinyatakan dalam pasal 1 ayat (4): Kasultanan Ngayogyakarta Hadiningrat, selanjutnya disebut Kasultanan, adalah warisan budaya bangsa yang berlangsung secara turun-temurun dan dipimpin oleh Ngarsa Dalem Sampeyan Dalem Ingkang Sinuwun Kanjeng Sultan Hamengku Buwono Senapati Ing Ngalaga Ngabdurrakhman Sayidin Panatagama Kalifatullah, selanjutnya disebut Sultan Hamengku Buwono. Pasal 1 ayat (5): Kadipaten Pakualaman, selanjutnya disebut Kadipaten, adalah warisan budaya bangsa yang berlangsung secara turun-temurun dan dipimpin oleh Kanjeng Gusti Pangeran Adipati Arya Paku Alam, selanjutnya disebut Adipati Paku Alam. Desentralisasi asimetris dalam hal ini terlaksana dimana negara mengakui dan menghormati Kesultanan dan Pakualaman yang ada di Yogyakarta.

Selanjutnya, hal-hal sentral dalam penerapan desentralisasi asimetris dalam Undang-Undang Keistimewaan DIY ini berkutat pada 5 (lima) permasalahan pokok yakni: 1. Tata cara pengisian jabatan, kedudukan, tugas, dan wewenang Gubernur dan Wakil Gubernur, 2. Kelembagaan Pemerintah Daerah DIY, 3. Kebudayaan, 4. Pertanahan, dan 5. Tata ruang.

1. Pengisian Jabatan Gubernur dan Wakil Gubernur. Perihal ini diatur dalam Pasal 18-29 UU No. 13 Tahun 2012. Persyaratan istimewa dalam UU Keistimewaan DIY untuk menjadi gubernur dan wakil gubernur adalah bertakhta sebagai Sultan Hamengku Buwono untuk calon Gubernur dan bertakhta sebagai Adipati Paku Alam untuk calon Wakil Gubernur. Kemudian untuk pemilihannya tidak melalui pemilihan langsung oleh rakyat (pilkada) melainkan penetapan oleh DPRD DIY kemudian hasil penetapan diusulkan pada Presiden melalui Menteri untuk mendapatkan pengesahan penetapan. Kemudian Presiden Republik Indonesia mengesahkan penetapan dan melantik Sultan Hamengku Buwono sebagai 
Gubernur DIY dan Adipati Paku Alam sebagai Wakil Gubernur DIY selama 5 (lima) tahun, namun tidak terikat dengan 2 (dua ) kali periodisasi masa jabatan.

2. Kelembagaan. Kelembagaan diatur dalam Pasal 30 ayat (1) yang menyatakan: Kewenangan kelembagaan Pemerintah Daerah DIY sebagaimana dimaksud dalam Pasal 7 ayat (2) huruf b diselenggarakan untuk mencapai efektivitas dan efisiensi penyelenggaraan pemerintahan dan pelayanan masyarakat berdasarkan prinsip responsibilitas, akuntabilitas, transparansi, dan partisipasi dengan memperhatikan bentuk dan susunan pemerintahan asli. Ketentuan mengenai penataan dan penetapan kelembagaan Pemerintah Daerah DIY sebagaimana dimaksud pada ayat (1) diatur dalam Perdais.

3. Kebudayaan. Kebudayaan diatur dalam Pasal 31 ayat (1): Kewenangan kebudayaan sebagaimana dimaksud dalam Pasal 7 ayat (2) huruf c diselenggarakan untuk memelihara dan mengembangkan hasil cipta, rasa, karsa, dan karya yang berupa nilai-nilai, pengetahuan, norma, adat istiadat, benda, seni, dan tradisi luhur yang mengakar dalam masyarakat $D I Y$. Ketentuan mengenai pelaksanaan kewenangan kebudayaan diatur dalam perdais.

4. Pertanahan. Pertanahan di atur dalam Pasal 32, yang menentukan:

(1) Dalam penyelenggaraan kewenangan pertanahan sebagaimana dimaksud dalam Pasal 7 ayat (2) huruf d, Kasultanan dan Kadipaten dengan Undang-Undang ini dinyatakan sebagai badan hukum.

(2) Kasultanan sebagai badan hukum merupakan subjek hak yang mempunyai hak milik atas tanah Kasultanan.

(3) Kadipaten sebagai badan hukum merupakan subjek hak yang mempunyai hak milik atas tanah Kadipaten.

(4) Tanah Kasultanan dan tanah Kadipaten sebagaimana dimaksud pada ayat (2) dan ayat (3) meliputi tanah keprabon dan tanah bukan keprabon yang terdapat di seluruh kabupaten/kota dalam wilayah DIY. 
(5) Kasultanan dan Kadipaten berwenang mengelola dan memanfaatkan tanah Kasultanan dan tanah Kadipaten ditujukan untuk sebesarbesarnya pengembangan kebudayaan, kepentingan sosial, dan kesejahteraan masyarakat.

5. Tata Ruang. Tata Ruang diatur dalam Pasal 34, yang menentukan:

(1) Kewenangan Kasultanan dan Kadipaten dalam tata ruang sebagaimana dimaksud dalam Pasal 7 ayat (2) huruf e terbatas pada pengelolaan dan pemanfaatan tanah Kasultanan dan tanah Kadipaten.

(2) Dalam pelaksanaan kewenangan sebagaimana dimaksud pada ayat (1), Kasultanan dan Kadipaten menetapkan kerangka umum kebijakan tata ruang tanah Kasultanan dan tanah Kadipaten sesuai dengan Keistimewaan DIY.

(3) Kerangka umum kebijakan tata ruang tanah Kasultanan dan tanah Kadipaten sebagaimana dimaksud pada ayat (2) ditetapkan dengan memperhatikan tata ruang nasional dan tata ruang DIY.

Salah satu keistimewaan lain yang dimiliki oleh Provinsi DIY dan berbeda dari pemerintahan daerah lainnnya ialah terdapat perdais (peraturan daerah istimewa) selain perda (peraturan daerah), Pergub (peraturan gubernur) dan Kepgub (Keputusan Gubernur). Di mana dalam perdais, Gubernur DIY mendayagunakan nilai-nilai, norma, adat-istiadat dan tradisi luhur yang mengakar dalam masyarakat dan memperhatikan masukan dari masyarakat DIY. Dalam konsepsi keistimewaan DIY, titik tekan keistimewaannya terdapat dalam 5 (lima) hal yakni pengisian jabatan Gubernur dan Wakil Gubernur, kelembagaan, kebudayaan, pertanahan, dan tata ruang yang disesuiakan dengan keinginan rakyat atau masyarakat DIY itu sendiri.

\section{c) Provinsi Papua, dan Provinsi Papua Barat}

Sejalan dengan nafas desentralisasi paska reformasi dan aspirasi daerah, masyarakat Papua menuntut untuk mengembangkan kekhasan budayanya dalam konteks NKRI melalui kebijakan pada tingkat nasional yang bersifat khusus. Tindakan ini direspon oleh pemerintah pusat dengan terbitkannya Undang- 
Undang Nomor 21 Tahun 2001 tentang Penyelenggaraan Otonomi Khusus bagi Provinsi Papua (UU Otsus Papua). Melalui kebijakan ini diharapkan dapat mengurangi kesenjangan antar Provinsi Papua dengan provinsi-provinsi lain dalam wadah NKRI, serta akan memberikan peluang bagi orang asli Papua untuk berkiprah di wilayahnya sebagai subjek sekaligus objek pembangunan. ${ }^{9}$

Secara spesifik UU Otsus Papua menyatakan bahwa tujuan Otonomi Khusus Papua adalah untuk mengurangi kesenjangan antara Provinsi Papua dan provinsi lain, meningkatkan taraf hidup masyarakat di Provinsi Papua, serta memberikan kesempatan yang lebih luas kepada penduduk asli Papua. Nilai-nilai dasar yang digunakan sebagai pijakan pemberlakuan Otonomi Khusus adalah perlindungan dan penghargaan terhadap etika dan moral, hak-hak dasar penduduk asli, Hak Asasi Manusia (HAM), supremasi hukum, demokrasi, pluralisme, serta persamaan kedudukan, hak, dan kewajiban sebagai warga negara. ${ }^{10}$

Latar belakang pemberian otonomi khusus kepada Papua juga ditegaskan dalam UU No 21 Tahun 2001. Penjelasan umum UU Nomor 21 Tahun 2001 menggambarkan bahwa pemberian otonomi khusus kepada Papua dilatarbelakangi oleh pengakuan negara terhadap dua hal penting. Pertama, pemerintah mengakui bahwa hingga saat terbentuknya UU tersebut terdapat permasalahan di Papua yang belum diselesaikan. Permasalahan itu meliputi berbagai bidang, baik dalam bidang politik, pemerintahan, ekonomi, maupun sosial dan budaya. Kedua, pemerintah mengakui bahwa telah terjadi kesalahan kebijakan yang diambil dan dijalankan untuk menyelesaikan berbagai persoalan di Papua selama ini. Pengakuan secara tegas bahwa apa yang dijalankan di Papua belum memenuhi rasa keadilan, belum memungkinkan tercapainya kesejahteraan, penegakan hukum, dan penghormatan terhadap HAM, khususnya bagi masyarakat setempat. Berbeda dengan kasus Aceh, otsus Papua tidak dapat dikatakan sebagai bentuk kesepakatan bersama, melainkan produk dari pemerintah pusat untuk meredam konflik yang terjadi di Papua. Jika otonomi khusus Aceh adalah bentuk tindak

\footnotetext{
9 Aryos Nivada, "Desentralisasi Asimetris; Politik Aceh dan Papua," imparsial.org (diakses tanggal 29 April 2018, format html, URL: http://www.imparsial.org/publikasi/opini/desentralisasi-asimetris-politik-aceh-dan-papua/) ${ }^{10}$ Ibid.
} 
lanjut dari penyelesaian konflik, maka otonomi khusus Papua dibuat sebagai upaya untuk menyelesaikan konflik. ${ }^{11}$

Berkaitan dengan bidang politik, Papua awalnya memiliki kekhususan dalam hal pemilihan gubernur dan wakil gubernur Papua oleh Dewan Perwakilan Rakyat Papua (DPRP). DPRP adalah badan legislatif Daerah Provinsi Papua, namun kewenangan itu kemudian dipangkas oleh pemerintah pusat pada zaman rezim pemerintahan Presiden Susilo Bambang Yudhoyono melalui Peraturan Pemerintah Pengganti UU Republik Indonesia No. 1 tahun 2008 Tentang Perubahan atas UU No. 21 tahun 2001 tentang otonomi khusus bagi Provinsi Papua. Dalam bidang politik sendiri, Papua memiliki beberapa kekhususan yang termaktub dalam UU 21 Tahun 2011 antara lain: ${ }^{12}$

1. Khusus pemilihan gubernur dan wakil gubernur Papua, kandidat wajib orang asli Papua sebagaimana diatur dalam pasal 21 huruf a UU 21 Tahun 2001. Orang Asli Papua adalah orang yang berasal dari rumpun ras Melanesia yang terdiri dari suku-suku asli di Provinsi Papua dan/atau orang yang diterima dan diakui sebagai orang asli Papua oleh masyarakat adat Papua;

2. Khusus pemilihan gubernur dan wakil gubernur Papua, tata cara pemilihan gubernur dan wakil gubernur ditetapkan dengan Peraturan Daerah Khusus (Perdasus) sesuai dengan peraturan perundang-undangan. Ketentuan ini terdapat dalam Pasal 11 ayat (3) UU 21 Tahun 2001. Perdasus sendiri adalah Peraturan Daerah Provinsi Papua dalam rangka pelaksanaan pasalpasal tertentu dalam UU No. 21 Tahun 2001.

3. Kewenangan untuk membentuk partai politik lokal. Dalam pasal 28 UU 21 Tahun 2001 diatur ketentuan mengenai partai politik lokal di Papua. Dimana penduduk Provinsi Papua dapat membentuk partai politik lokal melalui tata cara pembentukan partai politik dan keikutsertaan dalam pemilihan umum, disesuaikan dengan peraturan perundang-undangan. Rekrutmen politik oleh partai politik di Provinsi Papua dilakukan dengan

${ }^{11}$ Ibid.

12 Ibid. 
memprioritaskan masyarakat asli Papua. Namun untuk pembentukannya, partai politik wajib meminta pertimbangan kepada Majelis Rakyat Papua (MRP) dalam hal seleksi dan rekrutmen politik partainya masing-masing. Jadi berbeda dengan ketentuan pembentukan partai politik lokal di Aceh, dimana mekanisme seleksi dan rekrutmen kepengurusan parpol dilakukan secara mandiri oleh partai. Di Papua peran dan keterlibatan MRP terhadap rekrutmen kepengurusan partai politik lokal sangat besar. Namun dalam penjelasan UU No. 21 Tahun 2001 dinyatakan bahwa rekrutmen politik dengan memprioritaskan masyarakat asli Papua tidak dimaksudkan untuk mengurangi sifat terbuka partai politik bagi setiap warga negara Republik Indonesia. Kemudian permintaan pertimbangan kepada MRP tidak berarti mengurangi kemandirian partai politik dalam hal seleksi dan rekrutmen politik.

4. Sistem pemilihan melalui mekanisme 'Noken' di wilayah tertentu. Istilah Noken merujuk pada instrumen budaya yang berbentuk tas namun multifungsi bagi keseharian masyarakat Papua. Sejak tahun 1971 hingga saat ini, Noken telah digunakan sebagai alat pengganti kotak suara dalam Pemilu maupun Pilkada, di beberapa daerah di Papua. Jika kotak suara pada umumnya mengikuti standar yang ditetapkan oleh KPU RI, maka khusus di Papua, kotak suara digantikan dengan tas Noken. Pada tahun 2009 kebijakan ini dinilai konstitusional oleh MK melalui Putusan No. 4748/PHPU.A-VI/2009 terkait PHPU dari Kabupaten Yahukimo. Lalu diperkuat melalui salah satu putusan MK berikutnya yaitu No. 0632/PHPU-DPD/XII/2014 terkait dengan pelaksanaan Pileg 2014. Sistem penerapan Noken atau sistem ikat hanya dapat diakui di tempat- tempat yang selama ini memang selalu dilaksanakan secara terus-menerus. Menurut MK, sistem Noken tidak boleh dilaksanakan di tempat-tempat yang selama ini tidak pernah menggunakan sistem Noken. Apabila di suatu daerah sudah tidak lagi memakai sistem Noken, penggunaannya di daerah tersebut tidak lagi dapat diakui. Pemberian suara dilakukan dengan menggunakan sistem Noken dengan syarat tidak berlaku secara umum di 
Papua; bersifat lokal dan konkret; tidak melanggar prinsip pemilu yang jujur dan adil. Sistem Noken dalam Pemilu atau Pilkada banyak dipraktekkan oleh masyarakat wilayah pegunungan yang umumnya relatif terpencil dan jauh dari akses ibukota.

5. Jumlah anggota DPRP adalah 11/4 (satu seperempat) kali dari jumlah anggota DPRD Provinsi Papua sebagaimana diatur dalam peraturan perundang-undangan. Ketentuan ini tercantum dalam Pasal 6 Ayat 4 UU No. 21 tahun 2001. Artinya dengan adanya ketentuan ini, setiap jumlah alokasi kursi yang ditetapkan bagi Papua melalui ketentuan nasional, maka Papua berhak mendapat tambahan alokasi kursi sebanyak 11/4 (satu seperempat) kali dari jumlah yang ditetapkan oleh nasional.

6. Gubernur dalam menjalankan kewajiban selaku kepala daerah dan kepala pemerintahan provinsi, bertanggung jawab kepada DPRP. Ketentuan ini diatur dalam Pasal 18 Ayat 1 UU No. 21 tahun 2001. Hal ini berbeda dengan daerah lain di Indonesia, dimana gubernur sebagai wakil pemerintah pusat di daerah bertanggung jawab kepada Presiden. Sedangkan di Papua, gubernur selain harus bertanggung jawab kepada presiden juga kepada DPRP. Hal ini menjadikan karasteristik pemerintahan Papua mengarah ke semi parlementer. Dimana eksekutif bertanggung jawab kepada parlemen. Disisi lain pemahaman demokrasi presidensial di Indoensia, eksekutif hanya bertanggung jawab kepada rakyat bukan kepada DPR dikarenakan yang memilih eksekutif secara langsung adalah rakyat.

\section{d) Provinsi Aceh}

Bentuk asimetris politik di Provinsi Aceh dapat dicermati pada subtansi isi dari UU Nomor 11 Tahun 2006 tentang Pemerintahan Aceh. Undang-Undang tersebut menegaskan konsep asimetris yang secara politik masih berada dalam kerangka Negara Kesatuan Republik Indonesia (NKRI) yang merupakan subsistem dalam sebuah sistem pemerintahan secara nasional. Oleh karena itu, pemberlakuan otsus Aceh pada dasarnya bukanlah sekedar hak, melainkan 
merupakan kewajiban konstitusional untuk dimanfaatkan sebesar-besarnya bagi kemaslahatan masyarakat Aceh. ${ }^{13}$

Berkaitan dengan nama Provinsi Aceh dalam konteks hukum di Aceh terjadi berbagai perubahan beberapa peraturan perundang-undangan yang pernah berlaku dan yang masih berlaku yaitu melalui UU No. 24 Tahun 1956, UU No. 44 Tahun 1999, UU No. 18 Tahun 2001, dan UU No. 11 Tahun 2006. Berdasarkan keempat undang-undang ini nama Provinsi Aceh selalu mengalami perubahan dari Atjeh, Daerah Istimewa Aceh (DI Aceh), Nanggroe Aceh Darussalam (NAD), dan Aceh. Berikut ini adalah deretan historis dan yuridis penggunaan nama Aceh dari waktu ke waktu, yaitu: ${ }^{14}$

1. Undang-Undang Nomor 24 Tahun 1956 tentang Pembentukan Daerah Otonom Propinsi Atjeh dan Perubahan Peraturan Propinsi Sumatera Utara. UU No. 24 Tahun 1956 ini selalu dijadikan sebagai dasar hukum pembentukan peraturan perundang-undangan (konsideran mengingat) yang berkaitan dengan Aceh. Walaupun berada dalam satu undang-undang tetapi antara Aceh dan Sumut merupakan daerah otonom yang terpisah, berhak mengatur dan mengurus rumah tangganya sendiri. Menariknya, undang undang ini masih berlaku dan belum dicabut.

2. Undang-Undang Nomor 44 Tahun 1999 tentang Penyelenggaraan Keistimewaan Propinsi Daerah Istimewa Aceh. Undang-Undang ini menegaskan bahwa keistimewaan merupakan pengakuan bangsa Indonesia yang diberikan kepada daerah karena perjuangan dan nilai-nilai hakiki masyarakat yang tetap dipelihara secara turun-temurun. Nilai-nilai inilah yang membentuk karakteristik masyarakat di Aceh yang menjadikannya sebagai landasan spiritual, moral, dan kemanusiaan. Inilah yang kemudian melahirkan fokus pada empat bidang utama pembangunan yaitu penyelenggaraan kehidupan beragama, kehidupan adat, pendidikan, dan peran ulama dalam penetapan kebijakan daerah.

${ }^{13}$ Ibid.

${ }^{14}$ Ibid. 
3. Undang-Undang Nomor 18 Tahun 2001 tentang Otonomi Khusus Bagi Daerah Istimewa Aceh sebagai Provinsi Nanggroe Aceh Darussalam (NAD). Undang-Undang ini lahir seiring perubahan penerapan asas penyelenggaraan pemerintahan di Indonesia yang sebelumnya menganut asas sentralisasi menjadi desentralisasi. Dalam UU ini Aceh diberikan otonomi khusus untuk menjalankan rumah tangganya sendiri. Undangundang ini kemudian dicabut dengan berlakunya Undang-Undang Pemerintahan Aceh.

4. Undang-Undang Nomor 11 Tahun 2006 tentang Pemerintahan Aceh. Undang-Undang ini lahir dari hasil konsensus penyelesaian konflik yang terjadi antara pihak GAM dan Pemerintah Republik Indonesia. UndangUndang ini sendiri merupakan kelanjutan resolusi konflik dengan ditandatanganinya nota kesepahaman antara Pemerintah RI dan Gerakan Aceh Merdeka pada tanggal 15 Agustus 2005 atau yang lebih dikenal dengan MoU Helsinki. Masa perdamaian inilah lahir Undang-Undang Nomor 11 Tahun 2006 tentang Pemerintahan Aceh dan sekaligus mencabut UU Nomor 18 Tahun 2001 tentang Otonomi Khusus Bagi Daerah Istimewa Aceh sebagai Provinsi Nanggroe Aceh Darussalam (NAD). Undang-Undang ini kemudian menjadi dasar rujukan penyelenggaraan otonomi khusus seluas luasnya bagi Aceh pasca reformasi.

Merujuk pada pengaturan Undang-Undang Nomor 11 Tahun 2006 tentang Pemerintahan Aceh (UUPA) dapat dipahami berbagai bentuk desentraliasi asimetris pemerintahan Aceh yang termaktub dalam regulasi tersebut. Berdasarkan hasil kajian, maka didapatkan sebanyak 9 (sembilan) pasal yang memperlihatkan keasimetrisan pemerintahan Aceh. ${ }^{15}$

Pertama, dimulai dari penyelenggaraan Pemilihan Kepala Daerah (Pilkada) di Aceh yang berpedoman pada Qanun Aceh sebagaimana Pasal 66 Ayat 6 UUPA. Namun pada fakta pelaksanaannya, produk dari Qanun Pilkada hanya

${ }^{15}$ Ibid. 
sekedar formalitas sebagai dasar hukum legalitas pelaksanaan Pilkada dalam konteks lokal saja. Bahasa halusnya hanya memenuhi syarat saja. Terlihat pada praktek sekaligus pengalaman Pilkada Aceh tahun 2012 dan tahun 2017. Qanun Pilkada kerap terlambat disahkan sehingga Komisi Independen Pemilihan (KIP) Aceh kemudian menjadikan Qanun yang lama sebagai dasar hukum namun petunjuk pelaksanaan tetap berpedoman kepada undang-undang nasional dan peraturan Komisi Pemilihan Umum (KPU) Pusat. Khususnya di Pilkada 2017, dalam tahapan pencalonan KIP Aceh menggunakan peraturan khusus sebagai pedoman teknis pelaksanaan. Hal ini dikarenakan norma yang terdapat pada Qanun Pilkada sebelumnya yaitu Qanun Aceh Nomor 5 Tahun 2012 dinilai tidak lagi relevan untuk diterapkan di rezim Pilkada serentak.

Kedua, terlihat pada Pilkada gubernur, bupati, dan walikota di kabupaten/kota di Aceh dipilih melalui pemilihan yang diajukan oleh partai politik nasional, partai politik lokal serta calon perseorangan. Namun khusus calon perseorangan tidak lagi menjadi khas Aceh karena sudah diizinkan keberadaan calon perseorangan pasca putusan Mahkamah Konstitusi (MK). Aceh sendiri merupakan pioner calon perseorangan (independen/non partai). ${ }^{16}$

Ketiga, keberadaan KIP dalam menyelenggarakan Pemilu baik Pilkada, Pemilu Legislatif (Pileg) maupun Pemilihan Presiden (Pilpres), berbeda dari daerah lain. Di daerah lain penyelenggara pemilu disebut dengan sebutan KPU (Provinsi dan Kabupaten/Kota). Di Aceh penyelenggara Pemilu dilaksanakan oleh KIP Aceh untuk tingkat provinsi dan KIP Kabupaten/Kota untuk tingkat Kabupaten/Kota. KIP sendiri merupakan bagian dari KPU yang diberi wewenang oleh UUPA untuk menyelenggarakan pemilihan umum presiden/wakil presiden, anggota Dewan Perwakilan Rakyat (DPR), anggota Dewan Perwakilan Daerah (DPD), anggota Dewan Perwakilan Rakyat Aceh (DPRA) dan Dewan Perwakilan Rakyat Kabupaten/Kota (DPRK), pemilihan gubernur/wakil gubernur, bupati/wakil bupati, dan walikota/wakil walikota. Secara substansi, KIP Aceh dan KIP Kabupaten/Kota tidak berbeda jauh dari segi kewenangan dan fungsi dengan KPU Provinsi dan KPU Kabupaten/Kota lainnya. Perbedaannya hanya terletak

\footnotetext{
${ }^{16}$ Ibid.
} 
pada nomenklatur nama Komisi Independen Pemilihan (KIP) yang selanjutnya berpengaruh pada lambang KIP yang berbeda dari KPU di daerah lain. Dimana untuk KIP lambangnya sama Garuda Pancasila namun frasa Komisi Pemilhan Umum menjadi Komisi Independen Pemilihan. Kemudian proses seleksi komisoner KIP dilakukan melalui metode satu atap yang dilaksanakan oleh DPRA untuk KIP Aceh dan DPRK untuk KIP Kabupaten/Kota. Sedangkan tata kerja KIP diatur oleh Qanun Aceh dengan berpedoman kepada UU penyelenggara Pemilu yang berlaku secara nasional.

Keempat, Pengawas Pemilihan yakni Panitia Pengawas Pemilihan (Panwaslih) untuk mengawasi jalannya penyelenggaraan Pilkada. Sedangkan untuk mengawasi penyelenggaraan Pileg dan Pilpres dilaksanakan oleh Badan Pengawas Pemilu (Bawaslu) Aceh untuk tingkat provinsi dan Bawaslu Kabupaten/Kota untuk tingkat Kabupaten/Kota. Bawaslu Aceh hanya punya mandat untuk mengawasi Pileg dan Pilpres, mereka tidak punya mandat mengawasi Pilkada. Proses seleksi komisoner Panwaslih dilakukan oleh DPRA untuk Panwaslih Aceh dan DPRK untuk Panwaslih Kabupaten/Kota. Meski proses seleksi dilakukan oleh legislatif lokal, komisioner Panwaslih pilihan DPRA dan DPRK harus mendapatkan pengesahan dari Bawaslu Pusat yang merupakan amanat pasal 60 UUPA.

Kelima, keberadaan partai politik lokal (parlok) yang secara tegas diatur dalam Pasal 75 UU No. 11 Tahun 2006, yang kemudian telah dikeluarkan Paraturan Pemerintah No. 20 Tahun 2007 tentang Partai Politik Lokal di Aceh.

Keenam, berkaitan dengan Dewan Perwakilan Rakyat Aceh (DPRA/DPRK), bahwa jumlah anggota DPRA $125 \%$ dari ketentuan nasional, hal ini diatur dalam Pasal 22 ayat (3) UU No. 11 Tahun 2006. Juga dipilih melalui pemillihan umum yang diikut oleh partai nasional (parnas) dan partai lokal (parlok).

Berikutnya Ketujuh, kewajiban menjalankan syariat agamanya bagi calon kepala daerah di Aceh. Uniknya di Aceh, bagi pemeluk agama Islam setiap calon Pilkada, baik gubernur/wakil gubernur, bupati/wakil bupati, dan walikota/wakil walikota wajib mengikuti uji kemampuan membaca Al-Quran. Setiap calon 
Pilkada mestilah memenuhi nilai tertentu yang diuji oleh tim khusus uji kemampuan baca Al-Qur'an. Oleh karenanya, bisa saja secara administratif lainnya seorang calon Pilkada terpenuhi syaratnya, namun pada saat uji kemampuan baca Al-Qur'an tidak lulus maka akan menyebabkan gugurnya calon tersebut. Uji kamampuan baca Al-Qur'an ini dapat disaksikan langsung oleh seluruh masyarakat di Aceh, bahkan disiarkan secara langsung oleh televisi dan radio lokal.

Kedelapan, kekhususan dalam hal dukungan bagi calon perseorangan. Calon perseorangan di Aceh cukup memperoleh dukungan sekurang-kurangnya 3\% (tiga persen) dari jumlah penduduk yang tersebar di sekurang-kurangnya 50\% (lima puluh persen) dari jumlah kabupaten/kota untuk pemilihan gubernur/wakil gubernur dan 50\% (lima puluh persen) dari jumlah kecamatan untuk pemilihan bupati/wakil bupati atau walikota/wakil walikota sebagaimana diatur dalam Pasal 68 UUPA. Berbeda dengan ketentuan di UU Pilkada yang berlaku secara nasional, dimana dukungan calon perseorangan adalah berdasarkan dari jumlah Daftar Pemilih Tetap (DPT) terakhir. Oleh sebab itu secara nasional, dukungan dapat berbeda-beda tergantung besaran DPT di daerah setempat, sedangkan di Aceh metode dukungan bagi calon independen adalah flat $3 \%$ (tiga persen) bagi semua wilayah di Aceh.

Terakhir Kesembilan, bentuk asimetris politik Aceh yaitu kekhususan dalam hal dukungan bagi calon yang diusung oleh partai. Partai politik lokal, gabungan partai politik lokal, atau gabungan partai politik dan partai politik lokal dapat mendaftarkan pasangan calon apabila memenuhi persyaratan perolehan sekurang-kurangnya 15\% (lima belas persen) dari jumlah kursi DPRA atau 15\% (lima belas persen) dari akumulasi perolehan suara sah dalam Pemilihan Umum anggota DPRA di daerah yang bersangkutan sebagaimana diatur dalam Pasal 91 UUPA. Ketentuan ini berbeda dengan nasional, dimana untuk nasional calon yang diusung parpol harus mendapat perolehan paling sedikit 20\% (dua puluh persen) dari jumlah kursi DPRD atau 25\% (dua puluh lima persen) dari akumulasi perolehan suara sah dalam pemilihan umum anggota DPRD di daerah yang bersangkutan. 


\section{Inventarisasi Peraturan Perundang-undangan yang Mengatur/Berkaitan tentang Desentralisasi Asimetris}

Berdasarkan pebelusuran pada bahan hukum primer, paling tidak, terinventarisir hukum positif/peraturan perundang-undangan terkait/mengatur tenang desentralisasi asimetris berikut ini:

1. Pasal 18 ayat (1), 18A ayat (1), \& 18B ayat (1) Undang-Undang Dasar Negara Republik Indonesia Tahun 1945.

2. Ketetapan Majelis Permusyawaratan Rakyat Republik Indonesia Nomor XV/MPR/1998 Tahun 1998 tentang Penyelenggaraan Otonomi Daerah, Pengaturan, Pembagian, dan Pemanfaatan Sumber Daya Nasional yang Berkeadilan, serta Perimbangan Keuangan Pusat dan Daerah dalam Kerangka Negara Kesatuan Republik Indonesia

3. Ketetapan Majelis Permusyawaratan Rakyat Republik Indonesia Nomor V/MPR/2000 tentang Pemantapan Persatuan dan Kesatuan Nasional

4. Undang-Undang Nomor 2 Tahun 2001 tentang Otonomi khusus Bagi Provinsi Papua

5. Undang-Undang Nomor 35 Tahun 2008 tentang Penetapan Peraturan Pemerintah Pengganti Undang-Undang Nomor 1 Tahun 2008 tentang Perubahan atas Undang-Undang Nomor 21 Tahun 2001 Tentang Otonomi Khusus Bagi Provinsi Papua Menjadi Undang-Undang

6. Undang-Undang Nomor 11 Tahun 2006 tentang Pemerintahan Aceh

7. Undang-Undang Nomor 29 Tahun 2007 tentang Pemerintahan Daerah Khusus Ibukota Jakarta sebagai Ibukota Negara Kesatuan Republik Indonesia

8. Undang-Undang Nomor 13 Tahun 2012 tentang Keistimewaan Daerah Istimewa Yogyakarta

9. Undang-Undang Nomor 23 Tahun 2014 tentang Pemerintahan Daerah.

\section{Kesimpulan}

Desentralisasi asimetris di Indonesia merupakan sebuah keberlanjutan sejarah yang telah dimulai dari masa kolonial dan ditegaskan hingga saat ini 
dalam UUD NRI Tahun 1945. Sebagai sebuah realitas praktik pemerintahan daerah, legitimasi yuridis konstitusional dari desentralisasi asimetris tersebut dapat dirujuk dalam Pasal 18A ayat (1), dan Pasal 18B ayat (1) Konstitusi Republik Indonesia sebagai hukum tertinggi negara (the supreme law of the land). Desentralisasi asimetris menyangkut urusan yang fundamental terkait pola hubungan pusat dan daerah menyangkut desain kewenangan, kelembagaan, finansial dan kontrol yang berbeda.

Desentralisasi asimetris setidaknya dapat diberikan dengan pertimbangan: konflik, sejarah dan budaya, daerah perbatasan, ibukota negara dan pengembangan ekonomi. Dalam tatanan praktik ketatanegaraan, hanya terdapat 5 (lima) daerah setingkat provinsi yang memperoleh perlakuan khusus/istimewa oleh Pemerintah Pusat dengan desain desentralisasi asimetris yang berbeda-beda, yaitu, Daerah Khusus Ibukota Jakarta, Daerah Istimewa Yogyakarta, Pemerintahan Aceh, Daerah Otonomi Khusus Papua, dan Daerah Otonomi Khusus Papua Barat.

\section{DAFTAR PUSTAKA}

Bayu Dardias Kurniadi, "Desentralisasi Asimetris di Indonesia”, Makalah disampaikan pada Seminar di LAN Jatinangor tanggal 26 November 2012.

Andhika Yudha Pratama, "Pelaksanaan Desentralisasi Asimetris dalam Tata Kelola Pemerintahan Daerah di Era Demokrasi", Jurnal Pendidikan Pancasila dan Kewarganegaraan, Th. 28, Nomor 1, Februari 2015.

Aryos Nivada, "Desentralisasi Asimetris; Politik Aceh dan Papua," imparsial.org (diakses tanggal 29 April 2018, format html, URL:

http://www.imparsial.org/publikasi/opini/desentralisasi-asimetris-politikaceh-dan-papua/) 